\title{
STRUKTURA PRZESTRZENNO-CZASOWA SYMBOLU „NOCY” W DOKTRYNIE MISTYCZNEJ SW. JANA OD KRZYŻA
}

Mówiąc o symbolu „n o cy”, musimy uświadomić sobie fakt, iż znajdujemy się na płaszczyźnie okrytego welonem tajemnicy przekazu doświadczenia mistycznego. Dzieła św. Jana od Krzyża (1542 - 1591) przedstawiają drogę człowieka do zjednoczenia z Bogiem, opisując doświadczenie spotkania dokonujące się poza wszelkimi pojęciami zmysłowymi i umysłowymi w absolutnym wygaszeniu wszystkich władz poznawczych. Doświadczenie obecności Misterium Boga jest przeżyciem niezwykle głębokim i intymnym, trudnym do werbalizacji.

\section{PROBLEM EKSPRESJI DOSWIADCZENIA MISTYCZNEGO SYMBOL SANJUANISTYCZNY}

Uprzywilejowaną formą wyrazu tych niezwykłych treści jest dla Mistrza Karmelu poezja posługująca się różnymi obrazami, zapożyczonymi z biblijnych opisów zjednoczenia Boga z umiłowanym narodem, budzącymi niekiedy zdziwienie czytelnika zmysłowością i realizmem: „góry i rozłogi”, „łąki pełne zieleni”, „samotne doliny”, „wody, przestworza jaśniejące”, „góry rozkoszy”, „puszcz ostępy cieniste”, „skaliste groty”, „żywy płomień miłości”, „ręka miła”, „pochodnie ognia płonącego”, „otchłanie głębin”, „łono głębokie”, „piersi Umiłowanego”, „chata uciszona”, „,noc pełna ciemności”.

Św. Jan od Krzyża, świadomy trudności w interpretowaniu tych poetyckich obrazów zauważy w Prologu do Pieśni duchowej, adresowanym do matki Anny od Jezusa, przełożonej Karmelitanek Bosych w klasztorze św. Józefa w Granadzie:

Strofy te, Czcigodna Matko, wydają się napisane w zapale gorącej miłości ku Bogu, którego mądrość i miłość jest tak wielka, że, jak mówi Księga Mądrości, „sięga od końca aż do końca” (Mdr $8,1)$. Dusza też przepojona i pobudzona tą miłością wykazuje podobną obfitość i zapał w swoich wypowiedziach. Dlatego nie myślę bym tutaj wyjaśnil je w tej rozciągłości i bogactwie, jakich uży- 
cza im płodny duch miłości. Byłoby to zresztą znakiem nieznajomości rzeczy myśleć, że mistyczne pieśni miłości, jakimi są te strofy, można dostatecznie wyjaśnić słowami. Albowiem „Duch Sw., który wspomaga niemoc naszą, przebywając w nas, jak mówi św. Paweł, prosi za nami wzdychaniem niewysłowionym" (Rz 8,26), o to, czego my nie możemy zrozumieć ani pojąć na tyle, aby to wyjaśnić. Bo i któż może opisać to, co On pozwala zrozumieć duszom rozmilowanym, w których mieszka? I kto ośmieli się wyrazić słowami to, co On im daje odczuć? Kto wreszcie może wyrazić pragnienia, które On w nich wznieca? Na pewno nikt, nawet same te dusze, które to przeżywają. I to jest przyczyna, dla której nie w ścisłych naukowych określeniach, lecz raczej w słowach pełnych przenośni, obrazów i porównań dają nam one poznać nieco ze swych przeżyć i z pełności ducha wyjawiają sekrety i tajemnice" (PD Pr. 1).

Te „przenośnie, obrazy i porównania” nie mogą być dokładnie wyjaśnione, ponieważ ,powstały w chwilach porywów miłosnych i głębokiego zrozumienia mistycznych tajemnic", a wszelkie objaśnianie nie dorównuje głębi ich istotnego znaczenia. Hermeneutyka mistyczna, zaproponowana przez św. Jana od Krzyża, podkreślając rozziew między każdą interpretacją, a „głębią ich istotnego znaczenia" (PD Pr.1), zwraca uwagę na potrzebę poddania się przeżyciu prowokowanemu przez pojawiający się obraz, które to przeżycie może stać się pokarmem dla duszy w jej dążeniu do Boga: „Mądrość bowiem mistyczna wynikająca z miłości, o której mówią te strofy, nie musi być wyraźnie zrozumiana, by mogła spowodować w duszy miłość i skłonność uczuciową, gdyż rzecz ma się tu podobnie jak z wiarą, w której kochamy Boga choć nie możemy Go pojąć" (PD Pr. 2). Obraz, porównanie, przenośnia, należące do sfery przekazu przeżycia mistycznego, mają stać się początkiem nowego ruchu wyobraźni czytelni$\mathrm{ka}$, który poddając się tym obrazom będzie wchodził stopniowo w intymne spotkanie z Bogiem.

„Figury i porównania”, o których mówi Doktor mistyczny., będziemy określali mianem ,s y m bolu”, pojmując go (za współczesną teologią i filozofią ${ }^{1}$ ) jako „znak-obraz-strukturę” wskazujący na inną rzeczywistość i jednocześnie uobecniający ją. Symbol, rozumiany jako „znak”, odnosi się do przedmiotu, który ma zdolność wskazywania rzeczywistości nowej, transcendentnej wobec samego znaku². W takim ujęciu symbol ewokuje dwie warstwy semantyczne, odsyłając do różnych rzeczywistości. Ciemność odsyła do zjawiska nocy wyznaczającej przestrzeń ciszy i odpoczynku czy też samotności i niepokoju w zależności od przeżywającego podmiotu. Wtórnie ciemność i noc mogą wskazywać na cierpienie, odrzucenie lub spotkanie miłości. Komunikacja treści dokonuje się w określonym kontekście religijno-kulturowym, determinującym sposób odczytania „kodu symbolicznego”. Pole znaczeniowe symbolu sanjuanistycznego jest wyznaczane przez bogatą tradycję tzw. „mistyki ciemności”, mającej swój początek w biblijnych obrazach „ciemności”, „obłoku”

${ }^{1}$ Por. P. Rico e u r, Egzystencjai hermeneutyka, tł. S. Cich owicz, Warszawa 1975; P. Ti1lich, Symbol of Faith, [w:] Religions, Language and the Problem of Religious Knowledge, Bloomington 1968.

${ }^{2}$ P. R ic o e u r, Le conflit des interpretations. Essaie d'hermeneutique, Paris 1968, s. 16. 
i „chmury”, w które wchodzi człowiek, przeżywający spotkanie z Bogiem, i rozwijaną przez Orygenesa, św. Grzegorza z Nyssy, pseudo-Dionizego, mistyków reno-flamandzkich oraz anonimowego autora Chmury niewiedzy ${ }^{3}$.

Symbol, rozumiany jako struktura obrazowa, oddziałuje na odbiorcę najczęściej przez zmysły wzroku i słuchu, które pobudzają aktywność wyobraźni pełniącej niezwykle istotną funkcję w kreowaniu symboli. Opierając się na analogii, bądź podobieństwie, symbol odsyła do rzeczywistości transcendentnej, wprowadzając w emocjonalny kontakt ze światem przedstawianym ${ }^{4}$. Takie rozumienie symbolu pozwala wskazać na istnienie pewnych podobieństw z sakramentami świętymi, wskazującymi w rzeczywistość wiary. Symbol mistyczny wskazuje na rzeczywistość zjednoczenia z Bogiem poprzez miłość. Jako ustrukturowany obraz należy on do wyobraźni odgrywającej ważną rolę w życiu duchowym człowieka.

Wyobraźnia - jak zauważa J. Maritain ${ }^{5}$ - sytuuje się pomiędzy intelektem i zmysłami, tworząc obrazy oparte na danych zmysłowych: smak, dotyk, zapach, słuch, wzrok. Nie znamy do końca roli wyobraźni w przeżyciu wewnętrznym, możemy być jednak pewni, iż wpływa ona na aktywność człowieka, jego przeżywanie świata zmysłowego i duchowego. Poznanie języka symbolicznego umożliwia nie tylko bierne odczytanie sensu, ale pozwala na aktywne uczestniczenie w rzeczywistości uobecnianej przez symbol.

Symbol „nocy” wraz z pokrewnymi mu modyfikacjami „ciemności”, pojawiający się we wszystkich dziełach św. Jana od Krzyża, jest punktem kulminacyjnym jego doktryny mistycznej ${ }^{6}$, wyraża podstawową naukę o drodze człowieka do zjednoczenia z Bogiem. W dwu pierwszych dziełach (Droga na Góre Karmel i Noc ciemna) „noc” jest symbolem „panującym”; w Pieśni duchowej i w Żywym ptomieniu mitości, opisujących stan zjednoczenia przemieniającego symbol „nocy” - zawsze obecny - ustępuje pierwszeństwa symbolice „światła”.

\section{ANALIZA SEMANTYCZNA TERMINU „NOC”}

Aby poznać strukturę i funkcję „nocy” u św. Jana od Krzyża, musimy na początku uzmysłowić sobie fakt, iż pojęcie to ma charakter wieloaspektowy i odsyła do niezwykle bogatej rzeczywistości duchowej. Takie postawienie sprawy rzutuje na naszą analizę, która w pierwszej fazie będzie polegała na

${ }^{3}$ Por. J. D a n i el o u, Platonisme et theologie mystique, Paris 1944, s. 190 - 199 (roz. 2: Le ténèbre mystique); J. O r ci b a l, Saint Jean de la Croix et les mystique rheno-flamands, Paris 1966; $\mathrm{H}$. $\mathrm{Ch}$. Pu e ch, La ténèbre mystique chez le Pseudo-Denys l'Areopagite et dans la tradition patristique, „Etudes Carmélitaines” 23:1938 s. 33-53.

${ }^{4}$ Por. J. Marit a i n, L'intuition creatrice dans l'art et dans la poesie, Paris 1966; T. Ożóg, Symbol jako struktura pośredniczaca, „Rocznik Nauk Społecznych KUL” 11:1963 z. 2 s. 61 - 75 .

${ }^{5} \mathrm{~J}$. Maritain, jw.

${ }^{6}$ Por. J. B a r u zi, Saint Jean de la Croix et le probleme de l'experience mystique, Paris 1931; G. Mor e 1, Le sens de l'existence selon saint Jean de la Croix, Paris 1961 (t. 3: Symbolique). 
zbadaniu pola semantycznego wyrazu „noc”, tzn. wskazaniu specyficznych kontekstów, w jakich termin „noc” się pojawia, aby ustalić jego podstawowe znaczenia ${ }^{7}$. Jak wykazały obliczenia dokonane na tekście oryginalnym, słowo „noc” (noche) pojawia się ponad 300 razy w różnych kontekstach. Można ustalić jednak pewne stałe zestawienia, którymi posługuje się Mistrz Karmelu. Zestaw określeń odwołujący się do naturalnego zjawiska nocy, dający niezwykle plastyczny opis nocy kosmicznej, będącej podstawą tworzonego symbolu nocy: „noc ciemności”, „pełna błogiego szczęścia”, „milsza nad jutrznię różaną", „w chwilach gdy się rozlewa blask zorzy różanej”, ,zdobna w blask promieniejący”, „zapadanie zmroku”, ,północ”, ,jutrzenka”.

Drugi krąg pojęć związanych z nocą przenosi na płaszczyznę ascetycznomistyczną wskazującą na itinerarium duchowe duszy do Boga: „noc ciemna” (noche oscura), „noc zmysłów” (noche del sentido), „noc ciemna zmysłów” (noche oscura del sentido), „noc bierna zmysłów” (noche pasiva del sentido), „noc czynna zmysłów” (noche activa del sentido) „noc ducha” (noche del espiritu), „noc czynna ducha (noche activa del espiritu), „noc bierna ducha” (noche pasiva del espiritu), „noc oczyszczenia” (noche de la purgacion).

Kolejny zestaw wyrażeń, wśród których na pierwsze miejsce wybija się pojęcie „wiary”, wskazuje na pojawienie się w procesie mistycznym elementu nadprzyrodzonego - znaku działania Boga w duszy: „noc wiary” (noche de fe), „ciemna wiara”, „ciemności wiary”, „noc kontemplacji” (noche de contemplacion), „ciemna kontemplacja”, „kontemplacja wlana”, „teologia mistyczna".

Poza tymi podstawowymi wyrażeniami, które stały się terminami technicznymi języka mistyki, znajdujemy rzadsze zestawienia terminu „noc”, wskazujące na wartość uczuciową procesu wyznaczonego przez symbol „nocy”: „burzliwa i straszna noc” (tempestuosa y horrenda noche), „, noc bolesnej kontemplacji” (noche de contemplacion penosa), „noc oschła i ciemna” (noche seca y oscura), „błogosławiona noc kontemplacji” (dichosa noche de contemplacion), „szczęśliwa noc oczyszczenia zmysłów” (dichosa noche de la purgacion sensitiva), „ciemna noc ognia miłosnego" (oscura noche de fuego amoroso).

Określenia wyżej wymienione wskazują na niezwykły ładunek uczuciowy jako odzwierciedlenie głębokich procesów, które dokonują się w doświadczeniu określanym przez symbol „nocy”. Określają one negatywne uczucia lęku, cierpienia, udręk, męczarni.

Niejednokrotnie Doktor mistyczny używa synonimów słowa „noc”, wskazujących na nowe aspekty obrazu symbolicznego - do najczęściej spotykanych zaliczamy: „ciemności” (tiniebla, tinieblas), „obłok”, „chmura” (nube), „cień” (sombra), „mgła” (niebla). Terminy te odwołują się do bogatej tradycji

${ }^{7}$ M. J. Mancho Du que, El simbolo de la noche en San Juan de la cruz. Estudio lexico-semantico, Salamanca 1982. 
biblijnej i mistycznej, zwanej mistyką ciemności, przeciwstawianej mistyce światła. Obraz „ciemności” spotykany zarówno w Piśmie św. (psalm 17, Hiob, Jeremiasz, Izajasz, św. Jan), jak też u Ojców Kościoła (Orygenes, Klemens Aleksandryjski, św. Grzegorz z Nyssy, pseudo-Dionizy Areopagita, Mistrz Eckhart, bł. Suzo, Ruysbroeck) będzie wyznaczał proces wewnętrzny duszy zmierzającej do zjednoczenia z Bogiem. „Ciemności” mogą odnosić się z jednej strony do grzesznego stanu duszy, który przeszkadza w zbliżeniu się do Boga, z drugiej zaś są znakiem „ciemności boskich”, w których dusza poznaje Boga poza wszelkimi pojęciami rozumowymi, dlatego znajduje się ona w ciemności pozbawiona światła naturalnego.

Rzadsze wyrażenia, będące zestawieniem słowa „noc” $\mathrm{z}$ terminologią należącą do mistyki światła, podkreślają wewnętrzną ambiwalencję symbolu „nocy”: „promień ciemności” (rayo de tiniebla , 2 N 5,3), „ciemny ogień" (fuego tenebroso, $2 \mathrm{~N} 12,1)$.

Wśród synonimów słowa noc należy również zauważyć te, które wprowadzają znaną z tradycji ascetycznej kategorię oczyszczeń i umartwień będących przygotowaniem duszy do zjednoczenia z Bogiem: „oczyszczenie” (purificacion, $1 \mathrm{~S}$ 1.1) i „umartwienie” (mortificacion, 1S 3,1) zmysłów i ducha, które w procesie mistycznym zostają pozbawione naturalnego światła poznania oraz naturalnych pożądań i pragnień, aby dać miejsce jednemu tylko pragnieniu Boga. Na podobnej zasadzie pozbawienia zmysłów naturalnych pragnień, nie pozwalających oderwać się duszy od świata zmysłowego, pełni „ogołocenie” (desnudez, 1S 3,4), „samotność” (silencio, PD $13-14,25)$, „nic” (nada, 1S $4,3)$ i dotyczy upodobań, poznania.

W polu semantycznym „nocy” pojawiają się określenia, które wprowadzają kategorię przestrzeni w procesie określanym przez symbol „nocy”: „droga”, „ścieżka”, „wyjście”, „schody”, „drabina”, „góra”, „szczyt”: „Z trzech przyczyn nazywa się nocą ta droga, którą przechodzi dusza do zjednoczenia z Bogiem” (1S 2,1); „próżnia” (vacio, 1S 3,2), „przepaść”, „namiot”.

Analiza pola semantycznego terminu „noc” pozwala wskazać na struktury przestrzenno-czasowe pojawiające się w wyobraźni, w których porusza się dusza przeżywająca doświadczenie mistycznej drogi do Boga. Tak złożony obraz „nocy” wyznacza pierwszą i podstawową strukturę symboliczną, bazującą na naturalnym doświadczeniu zjawiska ciemności; jest nią ambiwalencja i współistnienie uczuć przeciwstawnych, wzbudzanych przez proces mistyczny, a porównywanych do naturalnego lęku, niepokoju i jednocześnie zachwytu i odpoczynku budzących się w wyobraźni wobec fenomenu ciemności. 


\section{STRUKTURA NOCY KOSMICZNEJ}

Symbol „nocy” ma swoje źródło w naturalnym doświadczeniu człowieka, opartym na percepcji i przeżywaniu fenomenu ciemności ${ }^{8}$. Ciemność, warunkując sposób widzenia rzeczy i świata, wpływa na człowieka i określa jego wyobraźnię, sposób pojmowania siebie samego i świata, w którym żyje, oraz jego relacje do świata duchowego ${ }^{9}$.

Obraz „nocy” obecny w symbolu sanjuanistycznym ukazuje całe bogactwo odbioru zjawiska kosmicznego, jakim jest brak światła i ciemność. Podstawową rolę w tworzeniu tego obrazu odgrywają zmysły wzroku i słuchu, operujące różnymi odcieniami ciemności, światła i ciszy. Noc mistyczna jest porównywana do „nocy ciemności” (N 1), „pełnej błogiego szczęścia” (N 3), „milszej nad jutrznię różaną" (N 5), do spoczynku „w chwili, gdy się rozlewa blask zorzy rumiany, jako muzyka ciszą przepojona, samotność, w której brzmią organy, uczta, co moc i miłość daje na przemiany” (PD 15), „zdobnej w blask promieniejący" (PD 39). Obraz ten jest kompletowany przez komentarze teologiczne pisane przez św. Jana od Krzyża do poematów: „noc i burza” $(2 \mathrm{~N} 1,1)$, „,burzliwa i straszna noc" (2N 7,3); określenia te akcentują negatywną wartość „nocy”. „Noc mistyczna” — na wzór tej kosmicznej — ma swoją wewnętrzną dynamikę, ukazującą poprzez następstwo faz rozwój procesu zmierzającego do zjednoczenia z Bogiem — ,zapadanie zmroku”, „północ” i ,jutrzenka”:

Te trzy rodzaje nocy sq właściwie jednq noca, która ma trzy części jak każdanoc. Pierwszq noc, tj. zmystów, można przyrównać do poczq̨tku nocy, gdy w mroku rozpływaja się wszystkie przedmioty. Druga noc wiary - jest podobna do pótnocy, zupetnie ciemnej. Trzecia noc, będąca udzielaniem się Boga, jest jakby zaraniem bliskim już światta dziennego (1S 2,5).

Pełny opis zjawiska „nocy” uzupełnia obraz „mroku” i „ciemności”, właściwy dla północy i będący najwyższym stopniem procesu mistycznego: $[\ldots] z u$ petna ciemność większa jest od mroku nocy. Nawet pośród ciemnej nocy jeszcze coś można zobaczyć, natomiast w mrokach zupetnych nic się nie widzi $(2 \mathrm{~S} 1,3)$. Obraz „nocy” otrzymuje nową perspektywę dzięki odniesieniu do biblijnego doświadczenia „nocy” w Księdze Hioba, ukazując jej groźny charakter: W okropnościach widzenia nocnego, gdy sen na ludzi zwykt przypadać, zdjąt mnie strach i drżenie, jakie musiała odczuwać dusza w tym zachwyceniu, gdy $\dot{z}$ $w$ swej naturze nie mogła znieść zjednoczenia się z duchem Bożym (PD 14-15, 18). Wyjaśniając zjawisko wewnętrznego niepokoju, doświadczane w „nocy mistycznej", Doktor Karmelu odwołuje się do ogólnoludzkiego doświadczenia nocnych ciemności, które budzą u człowieka ambiwalentne uczucia lęku i zachwytu zarazem:

${ }^{8}$ T. Merton, Szukanie Boga, Kraków 1983, s. 204 - 213; E. S te in, Nauka krzyża, [w:] Swiatto w ciemności, t. 1, Kraków 1977, s. 17-265.

${ }^{9} \mathrm{M}$. Eli a d e, Le symbolisme des ténèbres dans les religions archaiques, [w:] Polarité du symbole, Paris 1960; E. T. Re i m bold, Die Nacht in Mythos, Köln 1981. 
[...] tak jak w czasie, gdy się ludzie uktadaja do snu, jawi się im i przestrzega ich widziadto, zwane zmora, które ukazuje się w początkach zaśnięcia, między świadomością a snem, tak i tutaj daje zrozumieć, że w tym przejściu duchowym pomięd zy snem nieświadomości naturalnej i czujności poznania nadprzyrodzonego, który to stan jest początkiem zachwytu czy ekstazy, przejmuje człowieka strach i drżenie pod wptywem widzenia duchowego, które się wtedy udziela (tamże).

Również na podstawie powszechnego doświadczenia „ciemności” św. Jan od Krzyża wyróżnia w obrazie „nocy” element pozytywny, związany z przeżyciem ciszy i odpoczynku nocnego oraz doświadczeniem schronienia danego przez „noc”. Człowiek „kosztuje całkowitego spoczynku, odpocznienia i ukojenia spokojnej nocy, a równocześnie otrzymuje bardzo głębokie, lecz jeszcze niejasne poznanie Boga" (PD $14-15,22)$.

Opis zjawiska „nocy kosmicznej”, znajdującej dzięki ukrytym analogiom swoje odpowiedniki w przeżyciu mistycznym „ciemnego” spotkania z Bogiem, pozwala ustalić podstawową strukturę rządzącą wewnętrznym procesem, wyrażającym się w symbolu „nocy”, obejmującym cały kompleks obrazów pochodnych. Strukturą tą jest ambiwalencja nastrojów: przeciwstawne uczucia euforii, fascynacji, radości oraz cierpienia, lęku, niepokoju ${ }^{10}$.

\section{„Noc utrapienia”}

„Noc ciemna” w znaczeniu doświadczenia negatywnego, o nacechowaniu uczuciowym pejoratywnym, wyrażająca się w wyrażeniu: „,burzliwa i straszna noc", wskazuje na ból i cierpienie spowodowane niepewnością i wątpliwościami, które rodzą się w trakcie odrywania się człowieka od używania władz zmysłowych i duchowych $(2 \mathrm{~S} 12,6)$, a kontemplacja wprowadza w nią „,element boski" $(2 \mathrm{~N} 6,1)$. To gwaltowne przestawienie się z dyskursywnego sposobu poznawania Boga na kontemplacyjny, ogólny, obfituje w doświadczenia, porównywane do przeżyć proroków Jonasza i Jeremiasza. Wśród cierpień niepewności, agonii i śmierci doświadczają oni uczucia oddalenia od Boga, a nawet opuszczenia $(2 \mathrm{~N} 6,1-4)$. Niepokój przeżywany przez człowieka poddawanego biernemu oczyszczeniu zmysłów i ducha jest porównywany do cierpień Jonasza, znajdującego się w opresji morskiego potwora: Czuje się, jakby byta potknięta przez jakiegoś potwora i odczuwa cierpienia podobne do tych, jakie cierpiat Jonasz w brzuchu bestii morskiej (2N 6,1). Miejsce, w którym przebywa człowiek podczas takich cierpień, porównywane jest do „grobu ciemnej śmierci" (tamże), do wód zakrywających go po głowę (2N 6,3), czy też do przygniatającego ciężaru (2N 5,7).

Obrazy „nocy strasznej” nakładają się na wizje „głębokiej ciemności”, „cienia śmierci”, wzięte z języka biblijnego, i oznaczają rzeczywistość piekła

${ }^{10}$ Por. Lu ci e n-M a ri e OCD, L'experience de Dieu. Actualité du message de Saint Jean de la Croix, Paris 1968, s. 77 - 101 (roz. 4: Polarité du symbole). 
(2N 6,2), stan śmierci wiecznej (tamże, por. Ps 17,5 - 7). Tym bolesnym odczuciom towarzyszą wizje wrzucenia do „dołu najgłębszego, do ciemności i do śmierci" (tamże). Okropność obrazów odrzucenia czy odepchnięcia od Boga jest potęgowana przez ,jęki umierających" (tamże), które uzupełniają obraz „nocy” od strony zmysłu słuchu.

W miarę postępowania procesu mistycznego, cierpienia zewnętrzne stają się coraz bardziej subtelne, dotykając intymnych części duszy. Z jednej strony ból i wewnętrzne oschłości są powodowane przez wlewanie w nią „ciemnego światła boskiej kontemplacji” (2N 10,2), w którym poznaje ona swoją nicość i niegodność wobec Boga: Lecz w miejsce tego otrzymuje dusza tak wielka mitość $i$ zrozumienie wartości Boga, że największa z tego wszystkiego co cierpi iodczuwa wśród trudów tej nocy jest udręka na myśl, że straciła Boga, lub że jest przez niego odrzucona $(2 \mathrm{~N} 13,5)$. Z drugiej strony powodem cierpienia jest uświadomienie sobie niezdolności przyjęcia „boskiej kontemplacji”. Dopóki nie nastąpi przemiana władz duszy, „kontemplacja owa i miłosne poznanie udziela się duszy wśród przykrości i udręki miłowania” (2N 12,4). Działanie „ognia miłości” dotyka samej „substancji duszy”. Sprawia ból tak silny i głęboki, że „wydzierają się czasem z ust krzyki, jęki duchowe” $(2 \mathrm{~N} 9,7)$.

\section{„Noc radości”}

„Noc szczęśliwa” wskazuje na radość i euforię spowodowaną obecnością elementu nadprzyrodzonego w duszy, który wprowadza uczucie pokoju, pewności, odpoczynku: „o wzniosła szczęśliwości!” (1N), „nocy ty milsza nad jutrznię różaną!” $(5 \mathrm{~N})$, „noc spokojna” (PD $14-15,22)$. Radości „nocy” są spowodowane uspokojeniem części zmysłowej i podporządkowaniem jej duchowi; por. „chata uciszona” (2N): W tej pierwszej strofie wyśpiewuje dusza swoje szczęście, które znalazła w wyzwoleniu się ze wszystkich rzeczy zewnętrznych, pożądań i niedoskonatości, tkwiących w części zmystowej $(1 \mathrm{~S} 1,1)$.

Radość „nocy” płynie z wolności, pozwalającej dążyć do Boga bez przeszkód i doświadczać dóbr boskich, żyć nowym życiem ducha: „Przypadła więc duszy ta wzniosła szczęśliwość, bo Bóg uśpil wśród tej nocy wszystkich jej domowników, czyli uciszył wszystkie jej władze, namiętności, odczucia i pożądania tak zmysłowe, jak i duchowe” (2N 14,2); „Przez to wyjście osiągnęła najcenniejszą swobodę i wolność ducha" $(2 \mathrm{~N} 22,1)$.

„Noc szczęśliwa” jest znakiem obecności i bliskości Boga, odczuwanej głęboko w duszy: Swiatto to tak pochtania i wciaga w siebie duszę wśród tej ciemnej nocy kontemplacji $i$ stawia ja tak blisko, że tym samym oswobadza ja i uwalnia ze wszystkiego, co nie jest Bogiem $(2 \mathrm{~N} 16,10)$. Intymne poznanie Boga w zjednoczeniu jest odbierane na płaszczyźnie uczuciowej jako stan odpoczynku, ciszy: W tym śnie duchowym na piersi umiłowanego swego, dusza posiada i kosz- 
tuje catkowitego spoczynku, odpocznienia i ukojenia spokojnej nocy, a równocześnie otrzymuje bardzo gtębokie, lecz jeszcze niejașne poznanie Boga (PD 14 -15,22); Lecz ta noc cicha nie jest ciemna, lecz jest jak noc bliska poranku $w$ chwili, gdy się zaczynaja różowić zorze, gdyż ten spoczynek $i$ ukojenie $w$ Bogu nie sq catkowicie pozbawieniem blasków, jak noc ciemna, lecz sq ukojeniem i odpoczywaniem $w$ świetle Bożym, w coraz to nowym poznaniu Boga (PD 14-15,23). Kompleksowy w swoim bogactwie uczuciowym symbol „nocy" kreuje w wyobraźni przestrzeń symboliczną, w której rozgrywa się proces mistyczny.

\section{STRUKTURY PRZESTRZENNE SYMBOLU „NOCY”}

Wewnętrzna dynamika procesu mistycznego (będąca wypadkową sił naturalnych duszy dążącej do Boga i energii wlewanej przez łaskę) organizuje przestrzeń symboliczną w czterech podstawowych wymiarach: centrum, kierunek horyzontalny i wertykalny oraz rytm cykliczny ${ }^{11}$. W przestrzeni tej porusza się dusza będąca $w$ drodze do pełnego zjednoczenia $z$ Bogiem; przestrzeń ta jest nadrzędną kategorią wobec czasu, zbierając na tym samym poziomie różne okresy czasu i zapewniając ciągłość procesowi mistycznemu.

Przestrzeń symboliczna rządzona jest tą samą podstawową strukturą „nocy”, polegającą na łączeniu przeciwieństw (coincidentia oppositorum). Przestrzeń „nocy” jest budowana według dwu wielkich kierunków: wertykalnego i horyzontalnego, dlatego w wyobraźni pojawiają się obrazy „góry”, „schodów”, „wstępowania na górę”, ,drogi”, „przepaści”, „,jaskiń”, „głębokości”. Punktem odniesienia dla przestrzeni symbolicznej jest kategoria „środka" duszy, wokół którego @rganizują się wszystkie problemy doświadczenia Boga w duszy: Srodkiem duszy jest Bóg i gdy ona doszła do Niego wedtug wszelkich możliwości swej istoty $i$ wedtug zakresu swych dziatań $i$ sktonności, będzie w ostatecznym i najgtębszym swym środku, w Bogu (ŻPM 1,12).

\section{Wertykalizm przestrzeni ,nocy”}

Wertykalizm symbolicznej przestrzeni „nocy” jest wyznaczany przede wszystkim przez obraz „góry”, odwołującej się do Góry Karmel $(1 \mathrm{~S} 13,10)$, odgrywającej szczególną rolę w historii zakonu karmelitańskiego, ale jeszcze bardziej do góry z Księgi Wyjścia (WJ 34,3), na której Mojżesz spotkał Boga w ciemnej chmurze $(1 \mathrm{~S} 5,6)$. W obrazie „góry” odnajdujemy elementy tradycji mistycznej szczególnie silnie wyeksponowanej w dziele św. Grzegorza z Nyssy

${ }^{11}$ Por. G. B achelard, La poetique de l'espace, Paris 1974; Ch. A. Bernard, Theologia symbolica, Roma 1984; G. D u r a n d, Le strutture antropoligiche dell immaginario, Bari 1972; M. Eli a de, Images et symboles, Paris 1969. 
Życie Mojżesza, opisującym mistyczne zjednoczenie duszy z Bogiem, dokonujące się w oderwaniu od wszelkich pojęć zmysłowych i rozumowych.

Podobną funkcję w organizowaniu przestrzeni symbolicznej pełni obraz „wstępowania na górę” (1S 13,13), która jest „górą doskonałości” $(1 \mathrm{~S}$ 5,6), wskazującą na proces trudnych oczyszczeń ze wszystkiego, co wiąże ją ze światem zmysłowym: Znaczy to, iż dusza pragnac wstapić na górę doskonatości, by tam obcować z Bogiem, nie tylko musi się wyrzec wszystkich rzeczy i zostawić je na dole, lecz i pożądania, które sa jak zwierzęta, musi poskromić i nie pozwalać im zbliżyć się do tej góry (tamże). Podobną funkcję w strukturze przestrzennej wyobraźni mistycznej pełni obraz wznoszenia się ku „szczytowi”, jako ołtarzowi, na którym składa ona „ofiarę czystej miłości” (1S 5,7), czy wchodzenie po „drabinie doskonałości” (2N 18,2), mającej swój pierwowzór w „drabinie Jakubowej" (Rdz 28,12).

Kierunek wertykalny przestrzeni symbolicznej wydłuża się w „dól” przez wprowadzenie obrazów głębi: „głębokie jaskinie” (ŻPM 3,66), ,skaliste groty" (PD 37,3). Na płaszczyźnie przeżycia mistycznego obrazy te odnoszą się do władz zmysłowych i duchowych, drążonych w procesie oczyszczeń czynnych i biernych tak, iż stają się one zdolne przyjąć subtelne światło Bożej miłości: Gdy jednak te jaskinie sa próżne i czyste, powoduja nieznośne pragnienie, głód $i$ utęsknienie ducha. Tak bardzo cierpia, jak pojemne sa głębie tych otchtani, bo pokarm. którego brak odczuwaja, również jest pełen gtębi-jest nim Bóg (ŻPM $3,18)$. Podobnie obrazy „głębokiej próżni” $(2 \mathrm{~N} 6,4)$, czy „przepaści” $(2 \mathrm{~S} 29,5)$ rozszerzają zakres przestrzenny symbolu „nocy”, który łączy w sobie wysokość i głębokość. Ostatecznie w swoim ,najgłębszym środku” (ŻPM 1,14) następuje owo intymne i miłosne spotkanie duszy z Bogiem: Inie należy uważać za nieprawdopodobne, że na duszy doświadczonej, wypróbowanej, oczyszczonej w ogniu doświadczeń, prac i różnych pokus, a która pozostata zawsze wierna $w$ mitości - spetnia się w tym życiu to, co przyrzekt Syn Boży, mianowicie, że jeśli Go kto mituje, przyjdzie do niego Trójca Przenajświętsza i uczyni w nim swe mieszkanie $(\mathrm{J} 14,23)$ (ŻPM 1,15). Przestrzeń kreowana przez symbol „nocy”, zależna od „środka duszy”, jest dopełniana przez nieskończoność Boga zamieszkującego w człowieku w akcie miłości.

\section{Uporzadkowanie horyzontalne przestrzeni}

Przestrzeń wertykalna symbolu „nocy” jest uzupełniana przez linię horyzontalną w obrazie „nocnej drogi”, zbierającej razem wszystkie elementy procesu mistycznego. Obraz „drogi” podzielonej na etapy z punktem wyjścia i punktem docelowym przywołuje w świadomości całą tradycję duchowości chrześcijańskiej, która wskazywała na prowadzące do Boga etapy oczyszczenia, oświecenia i zjednoczenia. 
Poprzez utożsamienie „drogi nocy” z Chrystusem, który — jak zauważa św. Jan od Krzyża - sam o sobie powiedział: Ja jestem droga, prawdq $i$ życiem. Nikt nie przychodzi do Ojca inaczej, jak tylko przeze Mnie (J 14,6), obraz ten otrzymuje nowy punkt odniesienia, wprowadza nowe horyzonty przestrzenne, rozwijające się w nieskończoność:

\author{
Mój Ukochany jest jak góry wyżyny, \\ Jak samotne doliny wśród gajów tonące, \\ Wyspy osobliwe \\ Jak potoki rozglośnie szumiące, \\ Jak tchnienie wiatru miłośnie wiejące (PD 14).
}

Rozszerzenie horyzontu „nocy” do granic nieskończoności jest typowe już dla stanu zaślubin mistycznych i zapowiada całkowite zjednoczenie w małżeństwie mistycznym. Ostatecznie pojawia się obraz „lotu”, który jest typowy dla zjednoczenia w małżeństwie mistycznym, nad którym dominuje obraz „żywego płomienia miłości" i symbolika światła.

Charakterystyka struktur przestrzennych symbolu „nocy” u św. Jana od Krzyża pozwoliła ustalić istnienie przestrzeni w wyobraźni mistycznej, w·której porusza się podmiot doświadczenia mistycznego. Przestrzeń tworzona przez linię wertykalną i horyzontalną znajduje swój punkt odniesienia w „środku duszy", gdzie spotyka Boga. Ruch na zewnątrz, wyjście na górę i sama góra sugerują istnienie przestrzeni zewnętrznej, w której porusza się dusza. Jednocześnie istnieje wyraźna tendencja do schodzenia w siebie, do ,głębokich jaskiń”, „głębokich przepaści” kojarzących się z przeżyciem lęku, bólu, cierpienia oczyszczeń i oschłości. Ostatecznie schodzenie na głębię kulminuje w całkowitym zatopieniu się w najgłębszym „środku swej duszy”, gdzie mieszka Bóg i przez Niego wyjście w niezmierzone horyzonty miłości Bożej, która jest dla duszy poznawaniem tajemnic Boga.

\title{
STRUKTURA CZASOWA ,NOCY”
}

Czas symboliczny procesu określanego obrazem „nocy”, podobnie jak przestrzeń, różni się od pojęcia matematyczno-fizycznego i jest zależny od przeżywającego podmiotu. Na pierwszym miejscu ma strukturę linearną i jest realizowany zgodnie z następstwem fazowym ,nocy”. Sw. Jan od Krzyża mówi o trzech etapach nocy mistycznej: „zmierzch-północ-świt” (2S 1,1). „Noc czynna" nie trwa zwykle długo $(1 \mathrm{~N} 8,4)$. Pokusy i cierpienia „nocy biernej zmysłów", rozpoczynającej drugą fazę procesu mistycznego, do którego przechodzą nieliczni, przedłużają ją w czasie i nie jest jednakowa dla wszystkich: Trudno oznaczyć, przez jaki okres czasu musza dusze trwać w tym poście i pokucie zmysłów. Okres ten nie jest jednakowy dla wszystkich, jak również nie wszyst- 
kie dusze przechodza jednakowe pokusy. Wszystkim kieruje tutaj wola Boga odpowiednio do niedoskonatości, z jakich się dusze muszq oczyścić $(1 \mathrm{~N} 14,5)$. Doktor mistyczny uzależnia czas trwania „nocy” od możliwości duszy: Jeśli dusza jest podatna $i$ wytrwata $w$ cierpieniu, oczyszcza ja Bóg intensywniej $i$ szybciej. Dusze zaśstabe oczyszcza mniejszymi pokusami, ale za to powolniej, nieraz przez bardzo dtugi czas (1N 14,5). Określa ten czas na kilka dni: Nie trwaja jednak tak dtugo, jak sama noc ducha. Przechodzi chwila dłuższa lub krótsza lub kilka dni wśród tej nocy i burzy, a znowu powraca zwykta pogoda $(2 \mathrm{~N} 1,1)$. „Noc ducha”, przygotowująca do miłosnego zjednoczenia z Bogiem i będąca okresem niezwykle bolesnych oczyszczeń, zwykle trwa „dłuższy czas, nawet

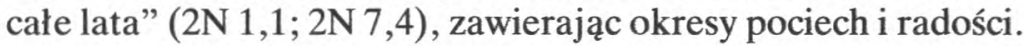

Symbol „nocy” jest również zbudowany według czasu rozwijającego się cyklicznie, zakładając powrót faz uprzednich. „Bierne oczyszczenie zmysłów” dokonuje się etapami, „okrywa je mrokiem, to znów oświeca” $(2 \mathrm{~N} 1,1)$; doświadczenia „północy”, tzn. „nocy ducha”, porównywane do mąk piekielnych „musi trwać przez kilka lat”, przerywane „chwilami wytchnienia” $(2 \mathrm{~N} 7,4)$. „Noc kontemplacji”, udzielająca miłosnego poznania Boga, nie trwa długo, „tylko na krótkie chwile dusza utrzymuje się w tym stanie” $(2 \mathrm{~N} 20,3)$.

Czas symboliczny w dziełach św. Jana od Krzyża ma charakter czasu „ścieśnionego” lub „rozszerzonego” w nieskończoność, zależnie od stopnia intensywności doświadczeń mistycznych, w chwilach bolesnych oczyszczeń, gdy duszy wydaje się, iż jest odrzucona od Boga i doświadcza cierpień czyśćcowych, czas trwa wiecznie (2N 6,2). Swiatło boskiej kontemplacji, wlewane do władz umysłowych, powoduje w duszy takie ciemności, iż traci ona w ogóle rachubę czasu: I nieraz wiele godzin mija w tym zapomnieniu, a duszy gdy wróci do siebie, czas ten wydaje się jedna chwila, lub zgota niczym $(2 \mathrm{~S} 14,10)$. Innym razem natomiast zapomnienie sprawia jakby znajdowała się zupełnie poza czasem (2S 14,11). Czas określany przez symbol „nocy” jest wyjściem poza kategorie czasu historycznego i partycypowaniem w czasie wiecznym: $O$ tej krótkiej modlitwie mówi się (Ekl 35,21), że przenika niebiosa. Jest krótka, bo wolna od granic czasu. Przenika niebiosa, bo dusza ta jest zjednoczona w poznaniu niebieskim (tamże).

*

$*$

$*$

Symbol „nocy” wyznacza przestrzeń osobowego spotkania człowieka z Bogiem; w „noc” wychodzi dusza, „by dokonać tak heroicznego aktu i tak niezwykłego dzieła, jakim jest zjednoczenie jej z Boskim Oblubieńcem” (2N 14,1). Symboliczna przestrzeń spotkania jest określana przez obrazy „ciemności”, „obłoku”, „ciemnych wód” i „ciemności otchłani” wskazujących na doświadczenie cierpienia i bólu związanego z oddaleniem od Boga i jednocześnie na 
niezwykłą bliskość obcowania z Nim. Uczestnicząc w przestrzeni kreowanej przez symbol „nocy”, człowiek wchodzi jakby w „namiot jego w ciemnej wodzie” (2S 9,2; por. Ps 17, 10-13), we „mgłę, w której mieszka Bóg” (2S 9,3; por.Wj 24,15 - 18), gdzie ciemności oznaczają przestrzeń wiary, miejsce spotkania z Bogiem: „Wszystkie te obłoki oznaczają ciemność wiary, w którą jest spowita Boskość, gdy się objawia duszy" $(2 S$ 9,3). Struktura przestrzenno-czasowa „nocy” poprzez kategorie horyzontalności i wertykalności oraz poprzez czas ,ścieśniony i rozszerzony w nieskończoność” prowadzi ostatecznie do rzeczywistości określanej przez św. Jana od Krzyża pojęciem „środek duszy”, zbierającej różne momenty dramatycznego przeżycia mistycznego i intymnego spotkania z Bogiem.

\section{LA STRUTTURA SPAZIALE-TEMPORALE DEL SIMBOLO DELLA „NOTTE” NELLA DOTTRINA MISTICA DI SAN GIOVANNI DELLA CROCE}

\section{Riassunto}

San Giovanni della Croce, è grande conoscitore dell'esperienza personale mistica e nello stesso tempo grande artefice della comunicazione dell'espierienza vissuta. Servendosi del simbolo della „notte" e delle immagini che fanno parte della simbolica „notturna” descrive la complessità del processo mistico che conduce all'unione con Dio. Il simbolo sanjuanista della „notte”, facendo parte dell'immaginario comune umano e partecipando ai meccanismi dell'inteletto e della psiche, viene organizzato dai grandi regimi della simbolica universale. Lo spazio e il tempo simbolico sono però differrenti dalle categorie matematicofisiche. Lo spazio „notturno” è determinato dalla situazione affettiva del soggetto spirituale, il quale nel „centro dell'anima” scopre la presenza di Dio. La coscienza spirituale del Mistico organizza lo spazio simbolico secondo le dimensioni di verticalità ed orizzontalità espresse nelle immagini delle „,caverne profonde”, dell',,abisso”, del „vuoto”, della „salita”, del „sentiero" et del „cammino”. Il simbolo della notte, mediante le immagini ad esso collegate, crea il luogo dell'incontro amoroso tra l'anima che ha attraversato il "lungo cammino della notte" e Dio. La „notte oscura” nelle immagini del „,sepolcro di oscura notte”, dell',abisso tenebroso" $(2 \mathrm{~N} 6,1-7)$, del "carcere angusto" $(2 \mathrm{~N} 1,1)$ costituisce la scena delle lunghe purificazioni e sofferenze „notturne” dell'allontanamento da Dio. Nello stesso tempo vissuta come „tenda” $(2 \mathrm{~N} 16,1)$, „nube oscura e luminosa” $(2 \mathrm{~S} 9,3)$ oppure „casa addormentata” indica totale intimità dell'anima dove essa sperimenta la presenza di Cristo, il suo Sposo.

Il processo designato dall'immagine della „notte” contiene la categoria del tempo simbolico, il quale rivela il valore di estensione e di contrazione. Il tempo „notturno”, come tempo linearestorico si sviluppa secondo le tappe designate dalle fasi della notte cosmica („annottare-mezzanottealbeggiare" - 2S 2,1). Dall'altra parte la "notte" conosce il tempo ciclico che presuppone il ritorno delle fasi suddette. Oltre al tempo lineare e ciclico il simbolo della „notte” determina la categoria del tempo vissuto la quale dipende dall'intensità dell'esperienza mistica. Nelle esperienze dolorose della „notte” raffigurate nelle immagini dell' „ombra e delle gemiti della morte” $(2 \mathrm{~N} 6,2)$ il tempo trascende l'inizio e la fine. Nelle „tenebre oscure dell'inteletto”, quando l'anima riceve la „luce di- 
vina”, il tempo simbolico si unisce all',eterno presente” esprimendo l'esperienza dell'eternità di Dio.

Il simbolo della „notte” con le sue strutture spaziali e temporali compie ruolo eminente nell'organizzare immaginario mistico, il quale fa parte dell'esperienza di Dio. Attraverso le immagini „notturne” il Mistico spagnolo tende ad esprimere tutta la complessità dei processi profondi che si svolgono nell'anima quando Dio la prepara a ricevere i suoi „segreti mistri”. 